\title{
Research and perspectives of distance learning
}

\author{
Vesna Buha \\ Educons University \\ Faculty of Project and \\ Innovation Management \\ Belgrade, Serbia \\ vesna.buha@pmc.edu.rs \\ ORCID iD: http:// \\ orcid.org/0000-0003-3239-3972 \\ Rada Lečič \\ Educons University \\ Faculty of Project and \\ Innovation Management, \\ Belgrade, Serbia \\ rada.lecic@pmc.edu.rs
}

\author{
Aca Jovanović \\ Educons University \\ Faculty of Project and \\ Innovation Management \\ Belgrade, Serbia \\ aca.jovanovic@pmc.edu.rs \\ ORCID iD: http:// \\ orcid.org/0000-0003-2284-5875 \\ Svetlana Mitrović \\ Educons University \\ Faculty of Project and \\ Innovation Management \\ Belgrade, Serbia \\ svetlana.mitrovic@pmc.edu.rs
}

\author{
Ljiljana Miletić \\ Educons University \\ Faculty of Project and \\ Innovation Management \\ Belgrade, Serbia \\ ljiljana.miletic@pmc.edu.rs \\ ORCID iD: http:// \\ orcid.org/0000-0003-3270-1891
}

\begin{abstract}
Growth and development of companies and economy in global business may be expected through innovation, new technologies, creativity, knowledge-based economy, investing in knowledge management and projects whose objectives are an ongoing development of learners, learning organizations and distance learning. Distance learning increasingly attracts attention of universities, companies and analysts who deal with modern technologies, management of human resources and skills, learning strategies, learners' achievements, and individual differences of users of these systems. The subject of this paper is to identify areas of distance learning which recognize the need for research and analysis, in order to shed light on essential aspects of problems in distance learning and test certain solutions. The paper offers an example realized by implementation of the Delphi method, as well as two case studies from Serbia - field research and experiment. The research and analyses, through previous categorizing and allocation and emphasizing of current topical areas, provide the ability to predict perspectives in which this area could further develop, with the aim of more effective and more efficient learning and higher quality achievements.
\end{abstract}

Keywords-distance learning, electronic learning, achievement, research approaches, Delphi method, experiment, knowledge management.

\section{INTRODUCTION}

Modern teaching, apart from traditional, offers more and more distance programs. Users choose from an increasingly complex offer and become more demanding, striving for greater efficiency and effectiveness in achieving their personal goals, keeping in mind options offered by modern technology.

Software packages for distance learning offer education divided into modules with clearly defined outcomes, programs which are precisely defined and achievable, designs which include audio-visual materials, materials which are theoretically grounded and applicable. Teaching materials presented in a variety of ways imply different activities of students, perceptions, processing of information, forms of learning phases, structures of teaching contents, as well as participation in various forms of communication that takes place during learning [1]. Educational institutions are able to continuously monitor realized results - achievements of students attending a particular module. This paves the way to personalize educational services based on specific properties and efforts of users.

In the context where desires, interests, educational and professional objectives of individuals (clients) intertwine with institutions aspirations to enter the market with more and more complex offers of educational packages for distance learning, it is necessary to have a research approach to different aspects of work. Thus, we treat distance learning as an area where different attitudes are "put to the test" in altered contexts, while various respondents` reactions are simultaneously monitored and taken into consideration.

Contemplating the need for researches whose subject is distance learning, we are faced with both marketing and socio-psychological aspects of work. Very broad and multidisciplinary scope of work in this area is observed. Because of the relative innovatively of distance learning, the need for research is large, and the effort is understandable to try to analyze the possible scope of work and the need for specific selections.

Therefore, the subject of this paper is to determine areas of distance learning which require research and analysis, in order to explain necessary aspects or test certain solutions. Aspects of teaching strategies, designing of contents, and personal strategies of students are again areas where diversities may be expected. 


\section{RESEARCH IN THE FIELD OF DISTANCE LEARNING - THEORETICAL REVIEW}

American Council on Education [2] defines the system of distance education as an integrated combination of technologies designed to support learning and training between persons not physically present at the same location (2001). To ensure flexibility, distance learning systems do not rely only on support of a single, but several technologies. Their popularity as online education grows because they: provide services to a large number of students; enable employees` improvement of knowledge in their professions, and enable them to acquire new qualifications; include a large number of experts; provide opportunities to everyone, regardless of the geographic location, to learn at their own pace; enable verification of achieved education in practice and adapt programs to specific needs and possibilities of students [3].

Examining the approaches adequate for distance learning for the purpose of marketing, it is necessary to review the general division of research. Table 1 shows differences in exploratory and conclusive research on key components [4].

TABLE I. DIFFERENCES BETWEEN EXPLORATORY AND CONCLUSIVE RESEARCH

\begin{tabular}{|l|l|l|}
\hline \multicolumn{3}{|c|}{$\begin{array}{c}\text { Differences between exploratory and } \\
\text { conclusive research }\end{array}$} \\
\hline $\begin{array}{l}\text { Research project } \\
\text { components }\end{array}$ & \multicolumn{1}{|c|}{ Exploratory research } & \multicolumn{1}{c|}{ Conclusive research } \\
\hline Research goal & $\begin{array}{l}\text { General: To generate insight } \\
\text { about a situation }\end{array}$ & $\begin{array}{l}\text { Specific: To verify insights and } \\
\text { aid in selecting a course of action }\end{array}$ \\
\hline Data needed & Vague & Clear \\
\hline Data sources & Ill - defined & Well-defined \\
\hline $\begin{array}{l}\text { Data collection } \\
\text { form }\end{array}$ & Open, rough & Usually structured \\
\hline Example & $\begin{array}{l}\text { Relatively small, subjectively } \\
\text { selected to maximize } \\
\text { generation of useful insights }\end{array}$ & $\begin{array}{l}\text { Relatively large; objectively } \\
\text { selected to permit generalization } \\
\text { of findings }\end{array}$ \\
\hline Data collection & Flexible; no set procedure & Rigid; well-laid-out procedure \\
\hline Data analysis & $\begin{array}{l}\text { Informal; typically non- } \\
\text { quantitative }\end{array}$ & Formal; typically quantitative \\
\hline $\begin{array}{l}\text { Conclusions/ } \\
\text { recommendations }\end{array}$ & Tentative & Final \\
\hline
\end{tabular}

Parasuraman [4] within the framework of exploratory research considers use of interviews with known individuals (experts), focus groups, secondary data analysis, case study; whereas for the purpose of conclusive research there are transversal researches running in a defined period of time and longitudinal, which are studies of repeated measurements where data are collected in several time intervals. Within the framework of conclusive researches, there are descriptive and experimental ones.

From the aspect of social psychology, acquiring of knowledge implies exploring social milieus, and they are grouped as 1. Experimental (laboratory and experiment in natural conditions), and 2. Nonexperimental (probable research or survey research and field research in local communities) [5]. Laboratory experiments are carried out when strict control of conditions is necessary to heedlessly consider subject problems (social dynamics, perception, decision-making). Conducting experiments in natural conditions provides a possibility for the research subject to run heedlessly similarly to everyday situation. Probable research or survey research is carried out on target groups, which are representative samples for the research subject. Field research is carried out within smaller social communities, groups and organizations, in order to review the research subject at its usual location.

\section{STRUCTURATION OF DISTANCE LEARNING}

Development of distance learning has been followed by numerous researches dealing with technology, curriculum, content, methods, economy, educational policy, management, monitoring of students`work in terms of outcomes, motivations, etc. Comprehensive nature of important topics for learning/electronic learning is of a multidisciplinary character, therefore complex for overall consideration. Several authors offered their own classifications, in an effort to group broad areas which require research, based on analysis of published papers dealing with the said topics. This is really a meta-analysis of the authors on topics of distance learning.

Scriven [6] analyzed papers (1991) dealing with distance learning published in the Journal of Distance Education in the first ten years. He classified them into nine categories: 1 . Students and their characteristics; 2 . Specific programs and courses; 3. Telecommunications and media; 4. Specific countries - practices and procedures; 5. Theory; 6. Course design and development; 7. Economics and management; 8. Counselling and student support; 9. Tutors, staff development, staff involvement.

In contrast to the previous author, based on a study made in India of 142 papers (1992) dealing with distance learning, Panda [7] classified research topics as follows: 1. Concept, growth and development; 2 . Curriculum, course planning and development; 3. Instruction and teaching; 4. Media and technology; 5. Learners and learning; 6. Institutional policy and management; 7. Economics; 8. Evaluation and program evaluation; 9. Staff development. In his research Panda uses system approach, viewing inputs (training, students, employee development), processes (two-way communication, services in support to students, evaluations) and outputs (achievements, a satisfaction of students, efficiency and effectiveness of the whole system).

Rourke and Szabo [8] analyzed contents of Canadian magazines for distance education in the period 1986-2001, and found the importance of analysis, management and promotion in the following fields: 1. Administration of budget planning, including flexibility, personnel and inter-institutional cooperation; 2. Evaluation of results, including value assessment, the success of courses, program and curricular content; 3. Basics of learning process (semantics, definitions, history and models); 4. Design, development and delivery of products); $5 \& 6$. Properties of instructors and students, including satisfaction, motivation, attitude, perception, 
teaching/learning style, cognitive style, gender, demography; 7. International perspectives regarding practices, procedures, roles of distance education in certain countries; 8. Applied technology and media (educational radio and TV, video and audio and computer conferences), and 9. Trends involving discussions and routes regarding general and special topics of the observed area.

Michael Graham Moore, editor of "The American Journal of Distance Education", offered the following list [9]: 1. Building and sustaining of effective delivery systems; 2. Course design and application of instructional design theories; 3 . Facilitating interaction between students and instructors; 4. Factors influencing students` achievements and satisfaction; 5 . Change of universities` roles and institutional culture; 6. Administrative and policy issues, including costeffectiveness and copyright.

Apart from the design of trainings and instructions, the focus is also on processes which because of contemporary development of technologies become more specifically oriented, constantly considering interaction between students and lecturers, with the aim to facilitate and motivate students, to result in greater efficiency and effectiveness [7]. The implied component at individual level is inclusion and involvement of participants, as the basis of learning, while outcome is achievement and satisfaction of students. Realization of these processes influences culture, educational institutions, and other important institutions. Copyright protection and economic aspects in these systems are always current topics.

\section{CASE STUDY ANALYSIS - RESEARCH AND PERSPECTIVES OF DISTANCE LEARNING}

Research projects dealing with different aspects of distance learning use different methods. One of them is the Delphi method. This method is often used in management/project management [10] and presents a systematic and organized collection of individual data/forecasting groups of experts on the topic under consideration. Naturally, the first step is to define the problem, which requires forecasting, then a group of experts is formed to participate in it. The forecasting horizon is defined then, the first series of questionnaires made for experts to offer their predictions and arguments. The median and IQR (Interquartile ranking) are calculated. Before completing second series of questionnaires, participants are informed on results of the first series of questionnaires. Thus, they can correct their attitudes and/or arguments, which partly determines predictions in the second round. In the last series of questionnaires (usually three or four), experts are asked to make final assessments.

As for research subjects that could be a part of electronic learning, it is also necessary to select the appropriate type of research procedure. Examples of good practice refer to procedures which provide an adequate context in which it is possible to examine the phenomenon and make relevant conclusions. The researcher then has numerous fields available relating to contents, as well as methodological procedures and tools.

\section{A. Expert assessment of individual research areas for distance learning}

A group applied the Delphi method at Fern University in Hagen (Germany) to forecast trends and areas of improvement. The research [11] included 25 experts from 11 countries (Australia, Brazil, Canada, China, Fiji, Germany, Ireland, New Zealand, South Africa, UK and USA). Results of 19 experts (Table 2) who participated in both phases of the examination [11]:

TABLE II. IMPORTANCE OF RESEARCH AREAS IN DISTANCE EDUCATION ASSIGNED BY PANEL MEMBERS

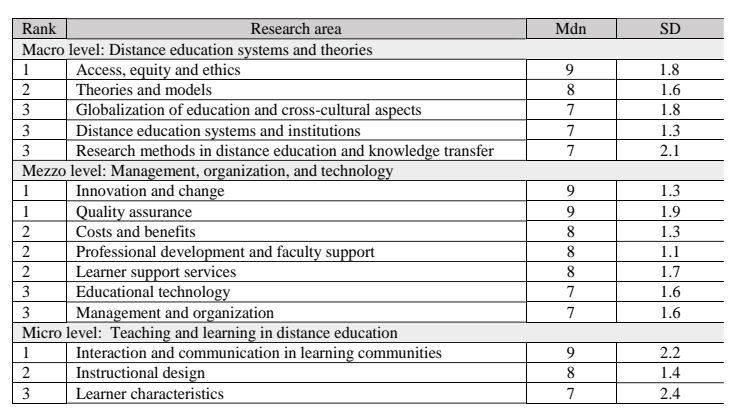

Experts identified three levels of distance learning: 1. Macro-theories and distance learning systems; 2. Mezzo - management, organization and technology; and 3. Micro-level - teaching and learning.

Figure 1 shows the established Inter Quartile Rank, (IQR), which points to a dispersion of responses ranging from $25-75$ percentiles.
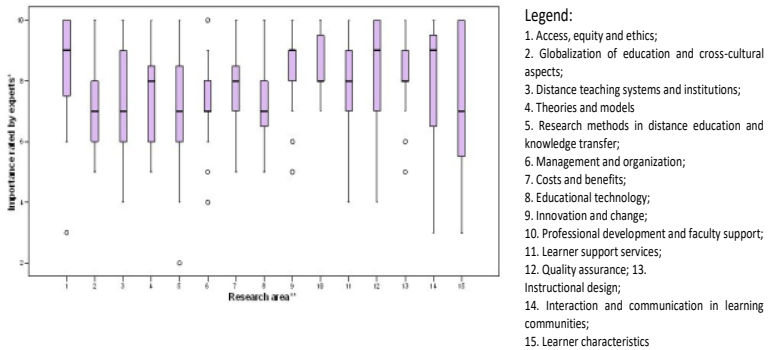

Fig. 1. Distribution of experts [11] ratings on significant research areas concerning distance learning [11]

Experts assessed as highly positioned Interaction and communication in learning communities (14), Access, equity and ethics (1), Innovation and change (9), Quality assurance (12), Learner support services (11), Professional development and faculty support (10), Instructional design (13), Learner characteristics (15). They are at positions 8-10 on the scale.

\section{B. Students`attitudes toward distance learning}

Field research is often applied in assessing different aspects of traditional/distance education. It is very important how students, users of curricula and 
distance learning systems, assess this type of teaching. Apart from attitudes of target groups, evaluation of how they would be treated by employers when trying for a job is also important. A research was conducted in Belgrade in 2011, in institutions that have curricula and resources for distance learning - the Faculty of Organizational Sciences and the College of Electrical Engineering and Computer Science in Belgrade [12].

\section{Research subject}

The subject of the research was to determine the attitude of students toward distance learning and their attitude toward applied software.

\section{Research goals}

The goal of the research was to determine how in distance learning students assess: 1. Transfer of contents; 2. Transfer of contents in application software; 3. Taking distant exams in comparison to traditional exams; 4. Preferences of studying methods: 5. Importance of educational institutions ' ratings and the fact that they introduce distance learning systems; 6. Advantages and disadvantages of distance learning in relation to the traditional one.

\section{Sample}

The sample consisted of 203 respondents from the University of Belgrade, students of the Faculty of Organizational Sciences (FOS) in Belgrade and the College of Electrical Engineering and Computing in Belgrade. Students were at undergraduate and master studies. Educational institutions were leaders in establishing the distance learning system. The overall group consisted of $54.7 \%$ of FOS students and $45.3 \%$ of students of the College of Electrical Engineering and Computing. Of these, $87.6 \%$ were at undergraduate studies, $11.8 \%$ at the college and $0.5 \%$ at master studies.

\section{Results}

When choosing a particular educational institution which offers distance learning, the rating the institution has, which it had acquired through traditional teaching forms, was the most important $(18.2 \%)$, or in a large degree $(50.5 \%)$. Educational institution, in a sense, guarantees the quality if it starts this type of education.

Based on the attitude of students concerning the desired studying method, and obtained ranging from 1 to 5 (1-the preferred form, 5-the least desired form of studying) Table was made, with the following order: 1.Traditional teaching method (1.99); 2.Traditional teaching with certain subjects taught through distance learning (2.01); 3.Distance learning with some subjects taught in a traditional way (2.63), and 4.Distance learning (3.43).

Slightly more than a fifth $(21.3 \%)$ of students use distance learning for some subjects, while the rest $(78.7 \%)$ do not.
About a third of respondents (28.1\%) think that with distance learning subjects can be covered to a large extent, most of them choose the central option (39.4\%), thinking that certain parts of contents cannot be explained that way. About one-third of respondents $(32.7 \%)$ believed that Applied software could be studied by distance learning, 59.2\% of them were indecisive, while the smallest number of them believe this subject cannot be taught by distance learning.

The largest number of students $(46.2 \%)$ thought it was easier to take a distance exam than a traditional one; a large number of them $(40.7 \%)$ believed it was equally difficult, while (13.1\%) believed it was more difficult to take a distance exam than a traditional one.

$4.90 \%$ of students expressed large motivation to study some subjects by distance learning, $21.20 \%$ of them in a degree, while $27.10 \%$ of them were indecisive. Other students were motivated in a small or a very small degree to use these learning systems.

Correlation Analysis (Pearson Correlations) shows that if the estimated degree of motivation for distance learning of individual subjects is higher, the level of confidence that teaching material can be "covered" by distance learning systems is higher. The correlation coefficient was 0.548 and is significant at the level of 0.01 .

TABLE III. ESTIMATE IN WHICH DEGREE STUDENTS TAKING SOME DISTANCE COURSES, IN COMPARISON TO STUDENTS WHO DO

NOT, WOULD TAKE SOME STUDYING TYPES
\begin{tabular}{|l|c|c|c|c|l|}
\hline $\begin{array}{l}\text { Estimate of the extent to which } \\
\text { students would take some types } \\
\text { of studies }\end{array}$ & $\begin{array}{c}\text { Students taking } \\
\text { some distance } \\
\text { courses }\end{array}$ & $\begin{array}{c}\text { Students not taking } \\
\text { any distance } \\
\text { courses }\end{array}$ & $\mathrm{F}$ & df1; df2 & $\begin{array}{l}\text { Significance } \\
\text { level }\end{array}$ \\
\hline Traditional way & 3.2250 & 4.3896 & 45.533 & $1 ; 192$ & Significant \\
\hline Distance learning & 3.3846 & 2.4040 & 30.523 & $1 ; 188$ & Significant \\
\hline Combination of both & 4.2857 & 3.5000 & 16.917 & $1 ; 192$ & Significant \\
\hline
\end{tabular}

The variance analysis (Table 3) shows that students with distance learning experience tend to opt for a combination of both learning methods, or only for distance learning, in comparison to students who have no distance learning experience. Students with no distance learning experience are more likely to opt for traditional learning.

Significance of individual teaching segments prepared with the use of new technologies was highly assessed. High scores were given (1-5), to multi-media (3.82), electronic books (3.76), databases (3.62), links to other learning contents (3.58), video material (3.35), animation (3.25). Students stated that databases would be used for exercises, learning, dictionaries, as part of teaching subjects. Multimedia would be used for presentations, learning, for explanations in interesting and attractive ways. Electronic books would be used for learning, writing papers, finding contents. Students use links to other Internet contents when learning, for easier explanation of contents and complex terms, preparing for exams, for writing papers. Students believe that animation should be used for presentations, learning in general, for simpler explanations, exercises. Students believe that video material should also be used in the learning process, to 
organize certain tutorials as video materials, for preparing presentations, to make lectures more interesting, etc.

A total of $20.7 \%$ of respondents did not use services which allow forming of social networks, e.g. Facebook, while all others did [13].

The difference between students who take some distance courses in comparison to those who do not (Table 4) is that those former believe they have quicker access to the necessary learning materials. The latter believe that face-to-face contacts with professors are far more important.

TABLE IV. DIFFERENCES IN OPINIONS OF STUDENTS WITH A DISTANCE LEARNING EXPERIENCE AND OTHERS

\begin{tabular}{|c|c|c|c|c|c|}
\hline \begin{tabular}{|c|} 
Agreeing with clams \\
concerning distance learring
\end{tabular} & $\begin{array}{l}\text { Students with } \\
\text { distance learming } \\
\text { experience }\end{array}$ & Other students & $F$ & df $1 ; \mathrm{d} f 2$ & Significance level \\
\hline Shows real working situations & 3.03 & 2.66 & 3.84 & $1 ; 184$ & not significant \\
\hline $\begin{array}{l}\text { Faster access to necessary } \\
\text { materials }\end{array}$ & 4.08 & 3.68 & 4.61 & $1 ; 185$ & significant \\
\hline $\begin{array}{l}\text { More interessing material is } \\
\text { presented }\end{array}$ & 3.54 & 3.24 & 2.39 & $1 ; 183$ & not significant \\
\hline $\begin{array}{l}\text { Reduces financial costs of } \\
\text { studying }\end{array}$ & 3.70 & 3.78 & 0.14 & $1 ; 184$ & not significant \\
\hline Reduces transport costs & 4.05 & 4.17 & 0.34 & $1 ; 186$ & not significant \\
\hline $\begin{array}{l}\begin{array}{l}\text { Provides greater comfort in } \\
\text { work }\end{array} \\
\end{array}$ & 3.97 & 3.79 & 0.93 & $1 ; 186$ & not significant \\
\hline \begin{tabular}{|l|}
$\begin{array}{l}\text { Missing contact 'face to face } \\
\text { with professsor" }\end{array}$ \\
\end{tabular} & 3.70 & 4.15 & 4.53 & $1 ; 184$ & significant \\
\hline
\end{tabular}

The assessment was also analyzed of whether employers treat differently those who graduated through distance learning, i.e., whether students believed employers should give priority to students who had traditional education, or both learning methods should be treated equally.

Chi-square (17.89) shows significant differences in students' beliefs on who would have priority with employers depending on the studying method. Students with no distance learning experience mostly believe employers should give priority to traditional studies, while students with distance learning experience believed both types of studies should be treated equally.

\section{Experimental determining students' results in traditional and distance learning}

For the purpose of creating and designing of contents for distance learning, preparation, organization of instructions and adaptation of existing teaching contents was done. This area of distance learning most directly leads to outcomes, attitudes and beliefs of students, and is based on involvement and interaction. In order to measure students` test results, an experiment was conducted in controlled experimental conditions. A total of 30 students from the College of Electrical Engineering and Computing/Department of Electronic Commerce were divided into two groups. The experimental group had a distance course in Marketing, while the control group had the same in the traditional way. The experiment was carried out to determine whether there were differences in students` test results.

Subject
To determine whether students` test results differ depending on the learning method (traditional versus distance learning).

\section{The aim}

To determine whether there are differences in results among distance learning students.

Sample

The sample included students of the College of Electrical Engineering and Computing in Belgrade. This is a non-randomized draft because the variable of abilities is selective in that it will be equal in relation to its group.

Variables

Independent variable: Intellectual abilities.

Dependent variable: Achievement of students on a test of knowledge.

\section{Experiment flow}

Psychological testing was organized at the College of Electrical Engineering and Computing (2011). For determining of intellectual abilities, KOG 3 instrument was selected. Student testing was carried out in completely correct conditions and had a fully expected development and flow. KOG 3 [14] is a psychological instrument that allows the manifestation of perceptual, verbal and non-verbal intellectual abilities. Total achieved result in this instrument enables reliable assessment of general intelligence (standardized on a sample of 52,000 respondents - Serbia). The instrument shows a high coefficient of reliability, homogeneity, validity, representativity.

A total of 30 students were tested. After testing was carried out, two groups were formed that are equal according to test results. It is to be expected that these equally divided groups, which learn in different ways (traditional versus distance learning) will have similar test results. In traditional learning, in classrooms they had marketing literature, presentations and video materials.

Traditional lectures were held in a standard way so as not to "favour" any method. Some teaching units were: Qualitative research methods; Quantitative methods of research, Selecting of market segments. A test was done for each of them. The tests were organized according to the principle of ticking correct answers and matching answers. In each test, a total of 12 points could be achieved ( 36 points in all). Students who studied in a traditional way (in classrooms) filled in a paper-pen test, while students who learned through distance learning (in a classroom equipped with computers) filled in an electronic version of the test set out in the Moodle section/Marketing/specific field of work.

For the presentation of contents through Moodle, links were prepared to specific terminology on www.wikipedia.org, as well as to adequate contents which could be downloaded, from www.youtube.com. Efforts were made for traditional lectures to be held in their usual way, with presentations and examples adapted to the contents. Current traditional teaching is 
done with materials prepared in electronic form. Although teaching through distance learning takes place with the contents available in .pdf format, .ppt, it enables fast access to information sources, downloading of video materials, viewing them in the context of time-teaching material, the possibility of returning to previous segment materials if needed.

\section{Results of the experiment}

After all lectures, students' test results were analyzed. Respondents were equalized by IQ. Zero hypothesis was set. H0 - there is no difference in the degree of acquired knowledge between the experimental and the control group of students if both distance and traditional lectures are of good quality. The distance learning group using contents placed on Moodle was the experimental group, while the traditional learning group was the control group. In this case: the independent variable is IQ, while the dependent variable is results of tests held immediately after a lecture.

The starting hypothesis $\mathrm{H} 0$ was that there would be no differences in results of the experimental and the control group, i.e., that results will be evenly distributed. Normality of distribution in the SPSS program was verified, Kolmogorov Smirnov test confirmed normal distribution, and accordingly, T-test was performed.

TABLE V. TEST OF INDEPENDENT SAMPLES

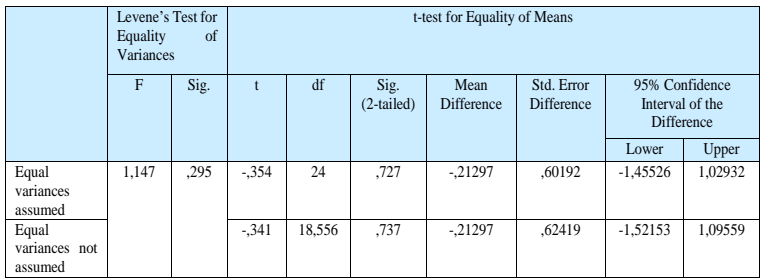

The first part of Table 5, Leven's test, shows $\mathrm{F}=1.147$ and estimated significance of 0.295 , indicating that the assumption of the distribution normality was not violated. Accordingly, data in the section Equal variances assumed are of importance. The difference between the arithmetic means is small - 0.213, as well as the difference between the standard deviations of 0.60 . T-test was -0.354 , and it can be concluded that there was no significant difference between the arithmetic mean of the experimental and control groups. It can be concluded that both groups mastered the contents without significant differences, regardless of the method of learning.

\section{CONCLUSION}

At a time when lifelong learning is the basic postulate of professional development for students, employees and job seekers, the importance of electronic learning is undeniable. For educational institutions, e-learning offers another quality, while for those who learn it offers another opportunity in combating competition and other everyday obligations. Organization of distance teaching re-tests offered models, providing new opportunities, perspectives, educational technologies, facilitation for those learning. Therefore, each of these potential topics can become the subject of research. Exploratory and conclusive research is encountered in research practice [4]. In situations when the subject of work is innovative, not well-known, researchers are more often inclined to exploratory model. It is an opportunity to identify all relevant aspects, possible links between variables, and possible causal relationships. In order to establish causal relationships with some certainty, it is more often approachable for conclusive research in which the goal of research, structure, formalized working procedures, and precise quantification is possible. Thus, conclusions are made with greater reliability, and there is increased security in decision making. Often both types of research are used in steps planned by research procedures or through activities implemented within projects. Transversal/Cross-sectional studies involve the collection and analysis of data in a specific time unit. If the phenomenon researched is a long-lasting one, it is approached by research of longitudinal type. Example of such research is panel researches where same/similar phenomena are measured in several time units.

This paper presents research results according to the Delphi method, cross-sectional survey and experiment. Analysis conducted by Hagen experts offers a general division of macro (distance learning theories and systems), mezzo (management, organization and technology) and micro-level (distance teaching and learning). Practical examples point to the complexity of each individual topic within the group and their variability in a unit of time. Systematically [7], inputs (training, students, employee development), processes (two-way communication, student support services, evaluation) and outcomes (results, students satisfaction, efficiency and effectiveness of the entire system) can be discussed.

Results of case studies - examples of experiences from Serbia - indicate that students highly evaluate use of multimedia, electronic (E) books, databases, links to data sources of subject matters, as well as the use of video materials, animations related to teaching. They also believe that distance learning offers faster access to contents, but they emphasize the absence of face-toface contact with lecturers. Rating of educational institutions acquired through traditional teaching is largely the basis of their confidence to opt for distance programs. Although during the research one-fifth of respondents already took some distance courses, they gave priority to traditional classes. Nevertheless, it already had some elements of distant courses. A third of respondents believed that Application software could be learned by distance learning. A third of respondents believe that distance exams are less stressful than traditional ones.

The experimental approach found that distance learning students achieve test results above average 
values, which leads to the conclusion that this way one can learn and expect adequate learning outcomes. T-test results showed there were no significant differences between the arithmetic mean of the experimental and control group. This indicates that the hypothesis is confirmed that results of distance learning students are as good as of students who learn in the traditional way.

Results of the case studies (research and experiment) in Serbia relate to research areas of the micro-level but also point to the need for other researches (mezzo and macro level) that would, at the time of accelerated IT development, monitor trends and development of electronic learning. Relying on research findings, aspects of knowledge management could become more reliable when making strategies, project management, quality assurance, cost management, and leadership.

Acquiring new knowledge and skills through electronic learning leads to improvement of quality, availability of educational programs and opening of a number of research areas. Reviewing of existing papers on the subject of distance learning for Serbia indicates they can also be grouped/categorized. Designing of new research projects provides the possibility of using different methodologies, technologies and conclusions on the micro, mezzo and macro level, which presents a platform of open perspectives in the field of distance learning.

\section{REFERENCES}

[1] V. Buha, V. Vasiljević, and S. Đenić, "Distance learning and personalization process", Technics, ISSN0040-2176, Union of Engineers and Technicians of Serbia, Belgrade LXXII, august 2017, pp. 591-600.

V. Buha, V. Vasiljević i S. Đenić, "Učenje na daljinu i proces personalizacije", Tehnika, ISSN0040-2176, Savez inženjera i tehničara Srbije, Beograd LXXII, avgust 2017, pp. 591-600.

[2] D. G. Oblinger, C. A. Barone, and L. B. Hawkins, "Distributed Education and Its Challenges: An Overview. American Council on Education", 2001, https://www.acenet.edu/news-room/Documents/DistributedEducation-and-Its-Challenges-An-Overview.pdf, Access date, April 2019.

[3] G. Milosavljević, "Training design", Faculty of Organizational Sciences, Belgrade, 2002, pp. 170-180.

G. Milosavljević, "Projektovanje obuke", Fakultet organizacionih nauka, Beograd, pp. 170-180, 2002.

[4] A. Parasuraman, "Marketing Research", Texas A \& M University, Addison-Wesley Publishing Company, 1991, pp. 119-149.
[5] N. Havelka, B. Kuzmanović, and D. Popadić, "Methods and techniques of socio-psychological research", The Center for Applied Psychology, Serbian Psychological Society, Belgrade, 1998, pp. 1-10 N. Havelka, B. Kuzmanović i D. Popadić, "Metode i tehnike socijalno-psiholoških istraživanja", Centar za primenjenu psihologiju Društva psihologa Srbije, Beograd, 1998, pp. 110.

[6] B. Scriven, "Ten years of 'Distance Education". Distance Education, 12(1), 1991, pp. 137-153.

[7] S. Panda, "Distance educational research in India: Stocktaking, concerns and prospects". Distance Education, 13(2), 1992, pp. 309-326.

[8] L. Rourke, and M. Szabo, "A content analysis of the Journal of Distance Education 1986-2001", Journal of Distance Education, 17(1), 2002, pp. 63-74.

[9] https://www.tandfonline.com/action/journalInformation?show $=$ aimsScope $\&$ journalCode $=$ hajd 20

[10] P. Jovanović, "Management", Theory and practice, Serbian Project Management Association, Belgrade, 2010, pp. 169219.

P. Jovanović, "Menadžment", Teorija i praksa, Udruženje za upravljanje projektima Srbije, Beograd, 2010, pp. 169-219.

[11] O. Zawacki-Richter, "Research Areas in Distance Education: A Delphi Study", International Review of Research in Open and Distance Learning, 10(3), ISSN: 1492-3831, 2009.

[12] V. Buha, "Researching marketing approaches in the distance learning process", Doctoral dissertation, Faculty of Organizational Sciences, Belgrade, 2012.

V. Buha, "Istraživanje marketing pristupa u procesu učenja na daljinu", Doktorska disertacija, Fakultet organizacionih nauka, Beograd, 2012.

[13] A. Labus, M. Despotović-Zrakić, B. Radenković, Z. Bogdanović, and M. Radenković, "Enhancing formal elearning with edutainment on social networks", Journal of Computer Assisted Learning, 31(6), 2015, pp. 592-605.

[14] B.Wolf, K. Momirović i Z. Džamonja, "COG 3", The Center for Applied Psychology, Serbian Psychological Society, Belgrade, 1992.

B.Wolf, K. Momirović, and Z. Džamonja, "KOG 3", Centar za primenjenu psihologiju, Savez društava psihologa Srbije, Beograd, 1992. 